\title{
Why Do Children Stay Out Of School In Indonesia?
}

\author{
Tatang Muttaqin' \\ Ministry of National Development Planning/BAPPENAS \\ Rafael Wittek, Liesbet Heyse, Marijtje van Duijn
}

\begin{abstract}
Municipal and household-level determinants for Indonesian children out of school are studied using multilevel analysis of 221,392 children in 136,182 households in 497 municipalities. The higher the poverty rate and public education expenditure per capita, the higher the likelihood that children drop out. However, a high(er) mean of municipality education expenditure significantly reduces children's likelihood to never attend school while a high(er) poverty rate significantly increases the likelihood that children will never attend school. At the household level, expenditure, spending on education, and head of household's educational background have a significant effect on reducing the number of children out of school.
\end{abstract}

Keywords: Indonesia, out-of-school, opportunity structure, municipality, household 


\title{
Why Do Children Stay Out Of School In Indonesia?
}

\author{
Tatang Muttaqin, BAPPENAS
}

\section{Introduction}

United Nations General Assembly resolution 44/25/1989 on the Convention on the Rights of the Child emphasizes the pivotal role education plays in human development. Even though many countries have ratified this convention, globally, there is still a large gap between its ratification and implementation. Approximately 69 million children, mostly girls, are still deprived of their right to basic education (UNICEF, 2014). In line with the global agenda, all citizens have the essential right to access to education as declared by the Constitution of Indonesia. Eager to improve access and quality of education, the People's Consultative Assembly in Indonesia amended the Constitution in 2001 by allocating 20 percent of the state budget to education (Blöndal, Hawkesworth and Choi 2009).

As a matter of fact, the Indonesian education system provides educational services for more than 50 million pupils from primary to senior secondary education who are enrolled in 258,000 schools (BAPPENAS, 2015). However, since 2006, there has been little progress in reducing the number of children who are out of school. This paper aims to simultaneously explain why some Indonesian children never go to school and others drop out.

The concept of 'out-of-school children' generally refers to children that should be in primary school but are not (UNESCO 2005). For this study on Indonesia, we broaden the concept to compulsory basic education, focusing on children aged 7-15 years who should be in primary and junior secondary schools. Theoretically, we depart from an opportunity structure approach, which refers to the scale and distribution of conditions to accomplish specific outcomes (Merton 1995, 25) and specifically to the rules and norms that individuals are supposed to comply with in order to achieve goals.

Because of Indonesia's decentralized system, the effectiveness of national policies depends heavily on municipalities (districts and cities) since these autonomous local governments have the authority and resources to manage primary and secondary education services. We therefore expect that municipality resources - such as public education expenditure per capita, poverty rate and average household education expenditure per municipality - will explain why some children are in school and others not (Colclough et al. 2000). Although municipalities might provide an adequate budget to abolish the educational fee, making it free, several children still might be out of school because their household resources are limited. Thus, we reason that household resources and characteristics will also influence children's opportunities to attend school (Pong \& Ju, 2000). Hence, the main research question of this paper reads: Which characteristics at the level of municipalities, households and children help to explain why children never attend or drop out from school in Indonesia.

This study makes three contributions to current research on educational attainment. First, though much research focuses on school dropout, only few studies pay attention to children who never set foot in a school in their entire life, especially in Indonesia (Shahnaz \& Naeem 2012; Suliman and El-Kogali 2010; Shindler 2010; Arunatilake 2006). Second, by empirically assessing the opportunities 
and constraints that these children face and by relating them to those of children who do attend school or have dropped out from school, we can provide a systematic comparison of these three groups in one study. This allows us to shed light on similarities and differences between children who never attend school and those who dropped out from school (Shindler 2010). Third, whereas previous studies have mainly focused on individual, family and community-related explanations (cf. Anderson 2010), we extend the focus by incorporating municipality factors and employ multilevel analysis that allows us to simultaneously examine the effects of children's, household and municipal levels. Thus, this study provides insights into the effect of municipality resources on school attendance. Policy makers in Indonesia's education sector may benefit from this analysis, since it disentangles to what degree and how does government investments in education reduce children out of schooling.

\section{Theoretical Framework}

We base our study on opportunity structure theory, which refers to the idea that opportunity, i.e. the chance to gain certain goals, such as education, is shaped by the way society or an institution is organized or structured (Roberts 2009). This theory suggests that people live in the social order that consists of culture and structure. While culture creates goals for persons in society, social structure may facilitate individuals to achieve those aims. A well-established society provides legitimate and appropriate ways to achieve one's goals (Merton 1968). Nevertheless, if there is a discrepancy between cultural goals and these structurally accessible means, individuals seek and use another means to achieve their objectives. In the case of children's education, this means that when a society (culture) holds the shared value that education is important, but the structure does not provide equal access to legitimate means for achieving the aspiration, higher levels of deviance will result. People will be more likely to create innovative alternatives for achieving the same goals everyone aspires to. For instance, the objective of education is to increase social mobility and when people are unable to attend school, they may go to work earlier.

Roberts (2009) classifies two dimensions in the opportunity structure. The push force is exerted mainly by ascribed status, such as family background and gender, and the pull factor comes from the government, as a service provider of education. In this paper, we focus on educational opportunities and constraints, particularly in terms of available resources at the municipality and the household-level.

At the municipal level, local government is a structure that may provide educational opportunities and constraints. For instance, when local governments have adequate budgets they can provide affordable and free education nearby, which also increases accessibility to schools. At the household level, we assume that mainly parents or other caretakers make the investment decision to send children to school, as in most other countries. We expect parents or caretakers to weigh future benefits of sending their children to school as an opportunity against the constraint of immediate costs. Children, but also other household members, may benefit from these investments (Huisman and Smits, 2009).

Only a few studies address children who never go to school. Using the individual and institutional categorization, some studies emphasize individual factors to explain why children never attend school. For example, Suliman and El-Kogali (2010) revealed that the opportunity costs of a child's time and a child's lack of interest in school influence children's non-participation in Egypt. Additionally, Shindler (2010) concludes that physical disability seems a substantial barrier to accessing education, especially in rural areas in South Africa. The institutional factors associated with children never attending school vary. For instance, Arunatilake (2006) explored the 
determinants of non-participation of 5-14 year old children in Sri Lanka and found that various demand and supply-side factors influences the decision of parents to keep children out of school, such as poverty, direct and indirect costs of schooling, cultural factors and job market relevance.

Building upon the notion of push and pull factors, as well as micro and macrolevel explanations, below we first discuss how local government resources provide opportunities and constraints for children to go to school and then continue by analyzing educational constraints and opportunities at the household level. Figure 1 provides a summary overview of our conceptual model. To simplify the hypotheses, we assume that the social mechanism leading to children never attending school or dropping out from school is quite similar.

Figure 1. Theoretical Framework

\begin{tabular}{|c|c|c|}
\hline Level 3: Municipality & $\begin{array}{l}\text { Municipality characteristics: } \\
\text { H1 Affordability ( -) } \\
\text { H2 Poverty rate (+) } \\
\text { H3 Municipality's mean } \\
\text { household investment ( -) }\end{array}$ & \\
\hline \multicolumn{3}{|l|}{ Level 2: Household } \\
\hline $\begin{array}{l}\text { H4 Resource scarcity (+) } \\
\text { H5 Education investment ( } \\
\text { H6 Human capital ( -) } \\
\text { H7 Female -head household (+) } \\
\text { H8 Accessibility ( -) }\end{array}$ & $x$ & $\begin{array}{l}\text { Household size (+) } \\
\text { Member below } 5(+) \\
\text { Poverty status (+) } \\
\text { Reside in urban ( -) } \\
\text { Non farming ( -) }\end{array}$ \\
\hline Level 1: Individual & $\begin{array}{ll} & \text { Child characteristics } \\
\text { - Gender } \\
\text { - Age } \\
\text { - Household relation }\end{array}$ & \\
\hline
\end{tabular}

\subsection{The impact of the municipality resources}

At the municipality level, we assume that government resources are important in providing opportunities for children to go and stay in school, especially because in the Indonesian decentralized system substantial financial resources and autonomy are distributed to the local government level to implement programs and improve education service (Sjahrir \& Kis-Katos 2011). This makes local governments crucial actors in providing access to education. In such a decentralized structure, we expect variation at the local level, because municipaities will differ in their public education expenditures. Such variations may influence the affordability of schools for households.

One important variation is that some local governments have decided to reduce the school fee, whereas others have not (Barrera-Osorio, Linden \& Urquiola 2008). Several municipalities provide schools with additional operational school assistance (BOSDA) on the condition that the school abolishes school fee. As a result, schooling might become free or more affordable, especially for the nine-year compulsory education. Lower cost and free education are expected to motivate parents to send their children to school, given that the costs of schooling, including fees, are often a key reason for parents to not send their children to school or to let them dropout (Liu, 2004). Based on these arguments, we predict that the lower the local government's public education expenditure per capita the more likely children are (a) to never attend school and (b) to drop out from school (H1).

Second, households residing in municipalities with higher poverty rates often lack community investment in child development (Pusponegoro, 2013). Consequently, they are likely to receive less social and economic support for child 
development, which may in turn reduce opportunities to go to school (BrooksGunn \& Duncan, 1997). Therefore, we predict that the higher the poverty rate of a municipality, the more likely children will (a) never attend school and (b) drop out from school $(\mathrm{H} 2)$.

Third, parental investment decisions need to be made regarding the education expenditures of their children. Parents' decision to invest in the education of their children might be influenced not only by the level of wealth but also by the community's aspirations as to education. The context and community in which they reside shape parents' decisions on education investments. Consequently, we expect that the lower the municipalities mean household education expenditure, the more likely children are to (a) never attend school or (b) drop out from school ( $\mathrm{H} 3)$.

\subsection{The impact of household socio-economic status (SES)}

At the level of the household, we expect that income, education investments, parents' educational level, household structure, and distance to school are important factors in parents' decisions on education. First, economically better off households can be assumed to have more opportunities and resources for spending money on their children's education (McNeal, 1999). Less wealthy parents may either need their children to contribute to the household income, through wageearning employment, or ask their children to take on additional tasks to free other household members for paid work (Suharti, 2013). Consequently, we expect the lower the household expenditure per capita in the household, the more likely that children will (a) never attend school or (b) drop out from school (H4).

Second, parents or caretakers' investments in education are associated with the degree of awareness of the importance of education. In modern societies, parents have fewer opportunities to achieve a good position in society for their children through direct occupational transmission or through the transfer of capital (Treiman \& Ganzeboom, 1990). As a result, education becomes more important as a vehicle of social mobility, which increases the importance parents attach to education, and therefore the price they are willing to pay. The household education expenditure per capita thus partly reflects how parents value education: it is not only determined by household wealth but also by parents' values and preferences for education. If they value education, then we expect them to invest more in education. As a result, we predict that the lower household education expenditure per capita, the more likely that children (a) never attend school or (b) drop out from school (H5).

Third, the parent's own educational attainment matters for their decisions on educational investment (Becker \& Nigel, 1994). Highly educated parents strongly prefer to increase their children's education because they recognize the importance of education. Thus, we expect that the lower the education level of the household, the more likely children are (a) to never attend school or (b) to drop out from school (H6).

Fourth, the household structure affects the availability of resources. Especially in female-headed households, children might be more constrained to go to school, because women in the developing world tend to be disadvantaged relative to men in their access to assets, credit, employment, and education (Lloyd \& Blanc 1996). We therefore expect that children in female-headed households are more likely to never attend school (a) or (b) will drop out from school (H7).

Finally, accessibility is crucial for children to be able to attend school, as previous studies show (e.g. Alisjahbana, 1999; Gitter \& Barham, 2007). Access can be hindered by the distance children have to travel to school. Especially in remote areas with poor transportation infrastructures, households in villages without a school may face prohibitive transportation times and costs. Parents might find it too dangerous to send their young children to another village and might wait until their children 
are older. As a result, we expect that school availability decreases the likelihood of children (a) never attending or (b) dropping out of school (H8).

\section{Methodology}

\subsection{Data}

We combined three official datasets from 2010. First, we used the National Socio-economic Survey (SUSENAS) 2010 from the Indonesian Central Bureau of Statistics (CBS) consisting of 1,178,494 individuals with 114 variables in 293,715 households with 134 variables. From this dataset, we selected the population aged 7-15 years, since it represents the official school ages during nine years of compulsory education. This selection results in 221,392 children in 136,182 households nested in 497 municipalities. Second, we used the Village Potential Statistics (PODES) from the CBS (2011) that provides information on the characteristics of about 65,000 villages. Third, we used the local government expenditure (LCE) dataset of 2010 as provided electronically by the Ministry of Finance (MoF, 2013). It contains 479 districts/municipalities, which is fewer than the SUSENAS dataset because decentralization in Indonesia led to newly created districts and municipalities. To reconcile the SUSENAS (497 municipalities) and the LGE dataset (484 municipalities after separating five municipalities), we added the data of the main municipalities for education expenditure to the new established 13 municipalities, giving the same total of municipalities as the SUSENAS dataset.

\subsection{Measurements}

Dependent variables. School enrolment was measured in three categories: "1" never attended school, "2" currently attending school (used as a reference category) and " 3 " not attending school anymore. Table 1 shows that 94.9 percent of children attended, approximately 3.6 percent were no longer enrolled and 1.5 percent had never attended school.

Independent variables. At the municipality level, we constructed three predictors: municipality education expenditure per student is constructed from the municipality education expenditure divided by the number of students in primary and junior secondary school, adjusted by the poverty line in each municipal to ensure comparability. Then, to reduce the undue influence of large expenditure per capita, we take the log of these numbers, ranging from 1.68 to 7.46 as exhibited in Table 1 . The second predictor is the mean of municipal household education expenditure. This is taken from an aggregate of the household education expenditure per capita, adjusted by the municipal poverty. We also converted these numbers to the log, ranging from 1.54 to 5.95 . The third predictor is the municipality's poverty rate. It is created from aggregating the household poverty status in a municipality.

Table 1. Descriptive statistics

\begin{tabular}{|c|c|c|c|c|}
\hline Levels and variables & Min & Max & Mean & Std. Dev. \\
\hline \multicolumn{5}{|l|}{ School participation (N=221,392) } \\
\hline Never & 0 & 1 & .015 & \\
\hline Enrolling & 0 & 1 & .949 & \\
\hline Not_anymore & 0 & 1 & .036 & \\
\hline \multicolumn{5}{|l|}{ Level 3 - Municipality (N=497) } \\
\hline Log of municipality public education per pupil & 1.68 & 7.46 & 5.256 & .545 \\
\hline Poverty rate at municipality & .02 & .50 & .155 & .094 \\
\hline $\begin{array}{l}\text { Log of municipality's mean household educ } \\
\text { expenditure }\end{array}$ & 1.54 & 5.95 & 4.129 & .670 \\
\hline \multicolumn{5}{|l|}{ Level 2 - Household (N=136,182) } \\
\hline Log Expenditure percapita & 3.08 & 9.83 & 5.825 & .491 \\
\hline Education expenditure percapita (binary) & 0 & 1 & .963 & \\
\hline $\begin{array}{l}\text { Head of household education: Below primary } \\
\text { (ref.) }\end{array}$ & 0 & 1 & .220 & \\
\hline - Primary & 0 & 1 & .326 & \\
\hline - Junior secondary & 0 & 1 & .162 & \\
\hline - Senior secondary and more & 0 & 1 & .292 & \\
\hline
\end{tabular}




\begin{tabular}{|c|c|c|c|c|}
\hline Head of household gender & 0 & 1 & .087 & \\
\hline School availability at village & 0 & 1 & .940 & \\
\hline \multicolumn{5}{|l|}{ Level I - Child ( $\mathrm{N}=221,392)$} \\
\hline Sex & 0 & 1 & .482 & \\
\hline Age (10.9 years as mid for centring) & 7 & 15 & 10.883 & 2.574 \\
\hline Relation to head of household: Child (ref.) & 0 & 1 & .881 & \\
\hline - Grandchild & 0 & 1 & .077 & \\
\hline - Relatives & 0 & 1 & .037 & \\
\hline - Others & 0 & 1 & .005 & \\
\hline \multicolumn{5}{|l|}{ Control variables at household level $(\mathrm{N}=136,182)$} \\
\hline Household size & 1 & 24 & 4.931 & 1.663 \\
\hline $\begin{array}{l}\text { Number of household members aged 0-4 years: } \\
\text { No child (ref.) }\end{array}$ & 0 & 1 & .645 & \\
\hline - One child & 0 & 1 & 301 & \\
\hline - Two child & 0 & 1 & .049 & \\
\hline - Three child & 0 & 1 & .005 & \\
\hline - Four child and more & 0 & 1 & .001 & \\
\hline Household poverty status & 0 & 1 & .150 & \\
\hline Place of residence & 0 & 1 & .395 & \\
\hline $\begin{array}{l}\text { Head of household source income: Agriculture } \\
\text { (ref.) }\end{array}$ & 0 & 1 & .442 & \\
\hline - Mining, industry and construction & 0 & 1 & .164 & \\
\hline - Services & 0 & 1 & .365 & \\
\hline - Others & 0 & 1 & .029 & \\
\hline
\end{tabular}

At the household level, five measures were used: (1) household expenditure per capita adjusted by the poverty line in each municipality. We then transformed this to the log of household's expenditure per capita adjusted by the poverty line as displayed in Table 1; (2) household's education expenditure per pupil adjusted by the poverty line in each municipality. This average education expenditure is not only spent for primary and junior secondary but also for preschool, senior high school and higher education. We coded "O" for households that do not spend money on education and " 1 to 20 " for 20 group percentiles of household education expenditure. We also coded them in binary with " $\mathrm{O}$ " as no spending on education and " 1 " for household spending on education; (3) heads of household's education level consisting of " 1 " for below primary/none (22.0\%), " 2 " for completed primary (32.6\%), "3" for completed junior secondary (16.2\%), "4" senior secondary and more (29.2\%); (4) female-headed household coding "O" for male and " 1 " for female with only 8.7 percent of households being female-headed; (5) accessibility with " 1 " as school available in village or less than three kilometers away for primary school and six kilometers away for lower secondary school (according to the official definition of accessibility), and "O" for unavailable. In general, schools are accessible in 94 percent of the cases.

Control variables. We include children's characteristics and other household's characteristics as control variables. Firstly, girls are more likely to drop out because gendered practices at the household level affect opportunities for girls, especially in developing countries. Secondly, older children are more likely to be out of school because growing older increases the opportunity cost of their time that leads to drop out (Ersado, 2005). Thirdly, a child's relationship to the head of household is a strong predictor of dropout or being out of school. Children's characteristics are important factors explaining why children are out of school but they are not the focus of our analysis.

At the household level, the following control variables were used: (1) household size, ranging from 1 to 24 (average being 4.9, SD 1.663); (2) households with a child below five years, consisting of none as " 0 " with about 64.5 percent, one child as "1" (30.1\%), two or three children as "2" (4.9\%) and " 3 " (0.5\%) correspondingly, and four and more children as " 4 " (0.1\%); (3) poverty status, with " 0 " for not poor and "1" for poor households, approximately 15 percent; (4) place of residence, with "O" for 
rural and "O" for urban, with about 39.5 percent residing in urban areas, (5) source of household income, with "1" for agricultural,(44.2\%), "2" for manufacturing/mining (16.4\%), "3" for services (36.5\%) and " 4 " for others (2.3\%).

\subsection{Analytical procedure}

Multilevel multinomial regression analysis using MLwiN 2.3 (Rasbash, Browne \& Goldstein, 2014) was applied. This method allows us to consider the hierarchical nature of our data, and permits us to test the effects of children's, household and municipal level variables (Snijders \& Bosker, 2012). A sequence of models was estimated, building up from the individual level, to test the hypotheses at all levels, including control variables at the household level. The models were estimated using MCMC estimation with initial burn-in length of 20,000 . This was followed by a monitoring chain with length 50,000 (with the final model rerun with 50,000 burnin and 100,000 chain).

\section{Empirical Findings}

To examine those children who are out of school within households and municipalities, we started our analysis by estimating a null model that included two random intercepts to compare both children who never attend school and children who dropped out from school to the reference category (children attending school).

Table 2. Multilevel Multinomial Regression Analyses for Children Aged 7-15 with Never Attend and Dropout from School as Dependent Variables

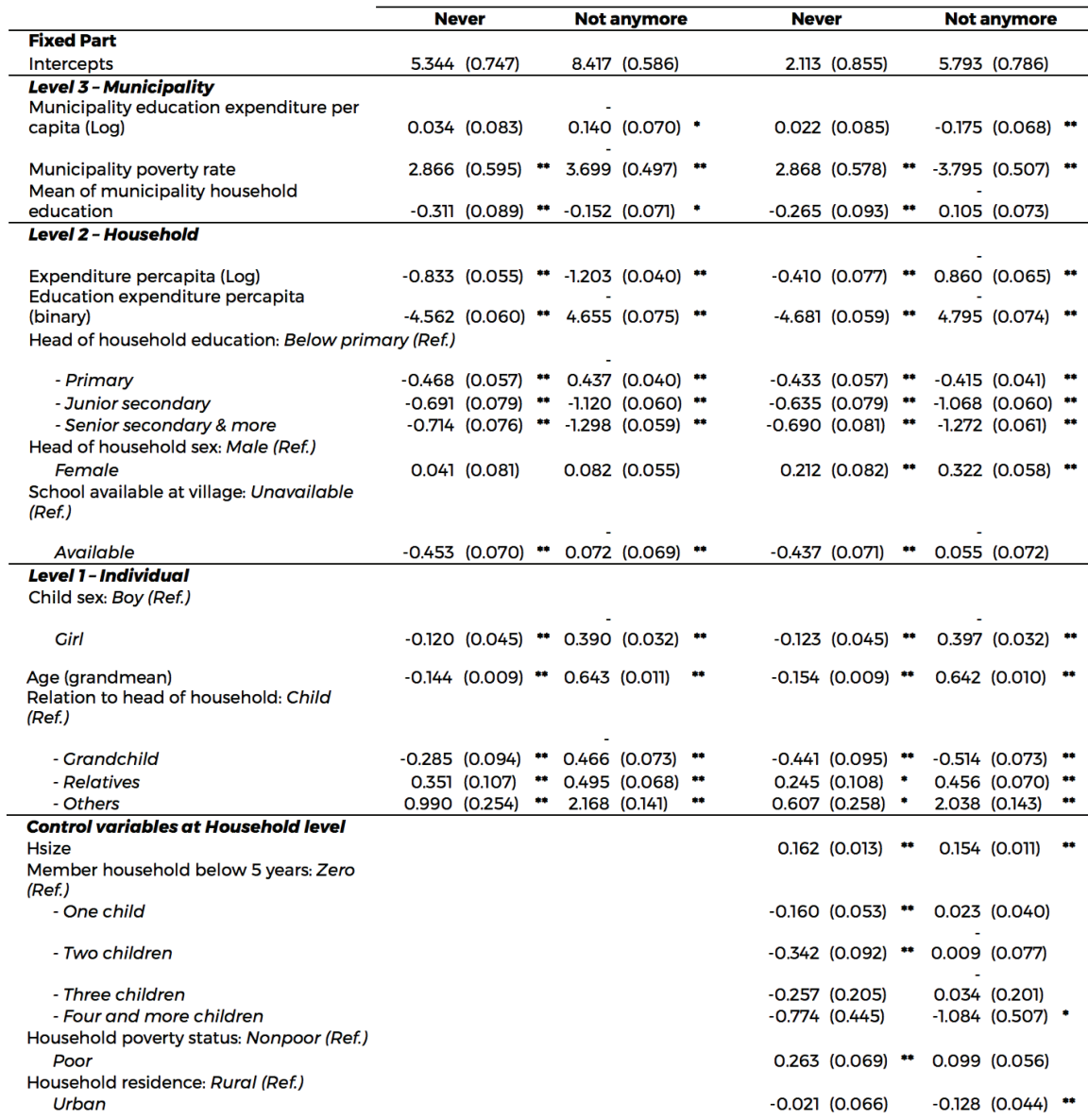




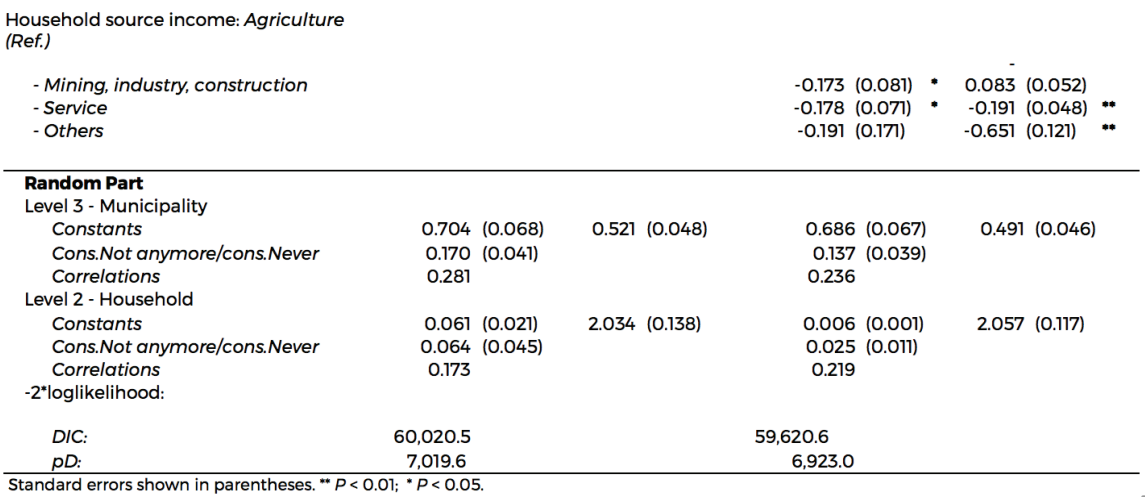

The multilevel multinomial analyses show that several child-level characteristics are related to the likelihood of children being out of school. Model 1 in Table 2 reports that children's characteristics explain the probabilities of children not at school. Compared to boys, girls are less likely to never attend and drop out from school. As expected, the age of children out of school has different effects. Growing older significantly decreases the probability of children never attending school but it increases children's chances to have dropped out from school. Position in household is also significantly related to the likelihood of non-attendance. Compared to the position of a child, being the grandchild of the head of household significantly decreases the likelihood of children to never attend or drop out from school. In contrast, in the position of a relative or 'other' significantly increased the likelihood to never attend and drop out from school.

\subsection{The impact of variations in municipality characteristics}

Table 2 demonstrates Model 1 without taking into account control variables and Model 2 by including control variables. After including control variables in Model 2 , the headed-female household becomes significantly link with increasing the likelihood of children never attending school and drop-out. On the other hand, the significant effect of the mean of municipality household education on the children's likelihood of dropping out disappears.

We now turn to the hypotheses formulated on the educational opportunity structure at the municipality level. As autonomous government entities, municipalities have a crucial role in providing primary and secondary education services and thus in facilitating opportunities for households to send their children to school. However, the municipality capacity to provide accessible and affordable school varies. Our first hypothesis proposed that the lower the local government's public education expenditure per capita, the more likely children are (1a) to never attend school and (1b) to drop out from school. The multilevel multinomial analyses show that local government's public education expenditure per capita does not have a significant effect on decreasing children's likelihood to never attend school ( $\beta=.034$ SE .083 and $\beta=.022$ SE .085, respectively) as exhibited in Model 2 (final model) of Table 2. Taking into account the variables at the household level as the final model provides clear evidence to refute hypothesis 1a: government expenditure does not decrease the likelihood of children never to attend school.

The results also show that the higher the local government's public education expenditure per capita, the lower the likelihood of children to drop out after taking into account all individual-level and household-level variables ( $\beta=-.140$ SE .070). 
Considering all household-level variables, the coefficient estimate increases slightly to $-.175 \mathrm{SE} .068$. Thus local government interventions as represented by public education expenditure per capita significantly reduce children's chances to drop out from school. Hypothesis $1 \mathrm{~b}$ is thus supported.

The second set of hypotheses suggested that the higher the poverty rate of a municipality, the more likely that children would (2a) never attend school or (2b) drop out from school. We found that the model results support hypothesis $2 a$. After taking into account all individual, household, municipal level and variables, the final result given in Model 2 (Table 2 ) shows that residing in a municipality with a higher poverty rate significantly increases the likelihood of children never attending school ( $\beta=2.868$ SE .578). Meanwhile, the results show that the higher the poverty rate of a municipality is significantly associated with a lower likelihood of children dropping out from school ( $\beta=-3.795$ SE .507).

Hypothesis 3 predicted that the lower the municipalities' mean household education expenditure, the more likely that children (3a) never attend school or (3b) drop out from school. Without taking into account the variables at the household level, the results of Model 2 in Table 2 show that a high(er) municipality mean household education expenditure significantly reduces the likelihood of children to never attend school ( $\beta=-.331$ SE .093) and drop out from school ( $\beta=-.152$ SE .071). However, after including all household-level variables, the results change for children who drop out from school. The results suggest that a high municipality's mean household education expenditure is not strongly or significantly related to the likelihood of children to drop out from school ( $\beta=-.105$ SE .073). These findings partially support hypothesis 3a: the higher the municipality's mean household education expenditure the more likely that children never attend school ( $\beta=-.243 \mathrm{SE}$ .076) but there is no clear evidence of such relationship for children's dropping out from school (3b).

\subsection{The impact of household characteristics}

We also looked at the impact of household attributes and their effect on children's school enrollment. Model 2 in Table 2 presents the effects of household expenditure per capita, household education expenditure per capita, femaleheaded households, school (un)availability as proxy for school distance, and head of household's educational background on children out of school.

The fourth set of hypotheses predicts that the lower the household expenditure per capita, the more likely children will (4a) never attend school or (4b) drop out from school. After taking into account all individual, household and municipal levels and control variables, our results in Model 2 of Table 2 fully support these hypotheses $4 \mathrm{a}$ and $4 \mathrm{~b}$. The results suggest that a high(er) household expenditure per capita diminishes the likelihood of children never attending school ( $\beta=-.410 \mathrm{SE}$ .077) and dropping out from school ( $\beta=-.860$ SE .065). The patterns of household expenditure for children who never attend school and who drop out from school are almost similar but the effect size of the household expenditure per capita is significantly larger in reducing the likelihood of children's dropping out from school than the likelihood of their never attending school.

The fifth set of hypotheses suggests that the lower household education expenditure per capita, the more likely it is that children will (5a) never attend school or (5b) dropout from school. The results in Model 2 of Table 2 support these expectations. Findings show that the household education expenditure per capita significantly reduces the likelihood of children both never attending ( $\beta=-4.681 \mathrm{SE}$ .059) and dropping out from school ( $\beta=-4.795 \mathrm{SE} .074)$. We also found that after including the variables at household level, the coefficient increased slightly both for children not attending school and dropping out from school. Although the patterns 
of household education expenditure per capita for children who never attend school and who drop out from school are in a similar direction, the magnitude of the household education expenditure per capita on lowering the likelihood of children's never attending school is larger than those of children's dropping out from school.

In addition, we examined both decile and percentile groups of the household education expenditure per capita and their effects. The results (not shown in Table 2) reveal that even though the household education expenditure per capita significantly decreases the likelihood of children being out of school, there is no difference in estimated effects among either decile or percentile groups of the household education expenditure per capita. Based on these results, we used the binary household education expenditure variable in the final model to simplify the model.

The sixth set of hypotheses predicts that the lower the education level of the household head, the more likely children are to never attend school (a) or to drop out from school (b). After including all individual, household, and municipal levels and control variables, Model 3 in Table 3 shows that compared to heads of households with below primary school education, a higher educational level of the head of the household significantly decreases the likelihood of children being out of school. Moreover, compared to children living in households where the head's education is below primary, children from households whose heads completed primary, junior and senior secondary or higher education are less likely to never attend school by $\beta=-.433$ (SE .057), $\beta=-.635$ (SE .079) and $\beta=-.690$ (SE .081), respectively.

Additionally, the same patterns are found for children who drop out from school but the estimated effects are bigger than for those who never attend school with $\beta=-.415$ (SE .041), $\beta=-1.068$ (SE .060) $\beta=-1.272$ (SE .061), respectively. In summary, our findings fully support the hypotheses, that the lower the education level of the household head, the more likely children are to never attend school (6a) or to drop out from school (6b).

The seventh set of hypotheses states the expectation that children in femaleheaded households are more likely to (7a) never attend school or (7b) dropout from school. Before considering the control variables at household level, no significant association is found between female-headed households and the likelihood of children attending school and dropping out from school, as illustrated in Model 1 of Table 2. After including the variables at the household level, Model 2 of Table 2 reveals that being part of a female-headed household increases the children's probability to never attend school ( $\beta=-.212$ SE .082) and to drop out from school $(\beta=-.322$ SE .058). The analysis also suggests that the effect of the female-headed households on children to drop out from school is stronger than on those never attending school. Hypotheses $7 a+b$ is thus confirmed.

Finally, the eighth set of hypotheses predicts that school availability decreases the likelihood of children to (8a) never attend or (8b) dropout from school. When we look at Models 1 and 2, we see that the effects of school availability are mainly the same. The findings reveal that school availability significantly reduces the children's likelihood of never attending school and this associated negatively although not significantly with children's chances for dropout. Then, after including the variables at the household level, Model 2 in Table 2 illustrates that the results are almost similar. School availability in a village significantly diminishes the likelihood of children to never attend school ( $\beta=-.437$ SE .071) but it is insignificantly related to reduce the likelihood of children to drop out from school ( $\beta=-.055$ SE .072).

All in all, the findings suggest that if schools are unavailable in a village and there is a need to transport children more than three kilometers for primary school and more than six kilometers for junior secondary school, children are less likely 
to attend school. Therefore, school availability significantly reduces the probability of children to never attend school (8a). This indicates that school unavailability is important to understand why some children never attend school but seemingly it is not a defining factor to explain why children drop out from school (8b). Concerning accessibility, as indicated by school availability in a village and distance to school, our findings reveal that the effect of school availability on children never attending school is stronger than for children dropping out.

\section{Discussion And Conclusions}

This paper sought to answer the question of which characteristics of municipalities, households and children explain why children never attend or drop out from school in Indonesia. Opportunity structure theory was used to argue that macro and micro attributes at both municipal and household levels facilitate or constrain children from attending school.

Using a multilevel approach, the hypotheses at the municipal level were supported only partially. First, efforts to improve access to schooling as indicated by the public education expenditure significantly reduce the likelihood that children drop out from school but no clear evidence was found that they decrease children's likelihood to never attend school. One may conclude from this that the government - through its expenditure - can help prevent children from dropping out from school but it may not help sufficiently to attract/encourage all children to attend school for the first time, such as children isolated in remote areas and street children in urban areas.

Second, regarding municipality poverty rate, our findings showed that residence in a municipality with a higher poverty rate significantly increases the likelihood of children to never attend school but it decreases the likelihood of children dropping out. This suggests that the poverty rate at the municipal level has an opposite effect on children to never attend or drop out from school. These interesting findings could be explained as follows: (1) the industrialized municipality might increase the average household income and provide job opportunities in the unskilled labor market. This may attract children to work and that leads to their dropping out from school. Because jobs are not available in non-industrialized municipalities, children residing there may stay longer at school. This situation is confirmed by the finding that children who live in households whose head works in the transportation, storage and communication sector have an increased likelihood to drop out from school (McCulloch \& Grover 2010); (2) the central government significantly increased education expenditure since 2009 as mandated by constitutional amendments. An enormous education budget was spent mainly on students completing universal compulsory education. As a result, primary and junior secondary schools, included in universal compulsory education, benefited from this policy. This is in line with previous experiences in economic crises, which showed that educational interventions such as providing nation-wide scholarships successfully prevented children from dropping out from primary school (Sparrow 2007). This policy provides more scholarships to higher poverty rate municipalities and that might be reducing the dropout rate. Since scholarships are distributed to children in school, not to children out of school, this policy will not decrease children's likelihood of never attending school.

Furthermore, the results show that the higher the municipality's mean of household education expenditure, the higher the children's likelihood of never attending school. Although the municipality's mean of household education expenditure is also related to reducing children's likelihood of dropping out, the 
effect is not strong enough to be significant. This thought-provoking finding implies that the size of average household education expenditure could be explained by other factors, which by themselves could be sufficient to have children stay at school. For instance, some municipalities had decided to abolish school cost with a consequent reduction in average household education expenditure at the municipality level (Paqueo \& Sparrow 2005). In addition, school-based management policy enables schools to determine their own school fee or make it free. This might increase school fee variations (Yonezawa \& Muta 2001). Consequently, the effect of the mean of household education expenditure may be weaker.

Impact of household and individual levels

At the household level, factors such as a household's wealth, investment in education and educational background of the head of the household are all significantly related to reduce children's' never attend and dropout rates. If the household is richer, invests more in education, and the household head has a higher level of education, the likelihood of children to never attend and dropout from school decreases significantly. Meanwhile, the fact that a woman is head of the household is not significantly related to the likelihood of children attending and dropping out but this relationship becomes significant after including the variables at the household level. It indicates that variables such as poverty and source of income are very important for the children's likelihood to never attend and drop out from school if they live in a female-headed household, mainly unemployed widows.

The findings show that school availability decreases the likelihood of children to never attend school but does not mitigate the chance of dropping out of school. If we look at the municipal level, these different mechanisms could be explained by the opportunity structure as follows. The proportion of children never attending school ranges from 10-87 percent in 16 municipalities in Papua Island (calculated from Susenas, CBS 2010). It indicates that the reasons for parents not sending their children to school may relate to school distance, difficult transportation and lack of infrastructure.

Surprisingly, the largest proportion of dropout, ranging from 8-10 percent does not occur in Papua Island (calculated from Susenas, CBS 2010). This indicates that school availability in a village is not clearly related to children dropping out from school. The dropout rate probably relates to labor market opportunity both in industrialized municipalities and in agricultural municipalities (Calculated from Susenas, CBS 2010). While job opportunities in industrialized municipalities attract children to drop out from school permanently, similar opportunities in agriculture municipalities attract children to work temporarily. Those job opportunities become a constraint for children going to school. Surprisingly, seven municipalities with zero dropout are mainly in Papua Island (calculated from Susenas, CBS 2010).

School non-participation has always been linked to a limited opportunity structure in developing countries. Our findings suggest that in the Indonesian case, resources (expenditure and education) matter, especially at the household level. However, the impact of various components of the opportunity structure at the municipal, household and individual levels are mixed and interrelated. We found that factors explaining why children never attend and drop out from school are quite similar for most of the variables included, but are substantially different for a limited set of factors, namely, public education expenditure per capita, poverty rate per municipality, municipality's mean household education expenditure, and the availability of schools.

\subsection{Policy implications}

What policy recommendations can be inferred from this study? First, as this study shows, government expenditure can have a positive effect on preventing 
school dropout. However, one should be aware that the amount of government money alone does not entirely explain the effect of government interventions on children's school enrollment. Focus on spending and quality of spending, in terms of corruption for example, are potentially equally important explanations. In terms of focus on spending, unfortunately our analyses could not shed light on the effect of various government interventions or educational activities on improving school enrollment. Also, we could not include indicators for the quality of spending. We are therefore very careful to draw policy implications from the effect this study lacks, namely of government expenditure on children's likelihood to go to school for the first time. However, in combination with the strong positive effect of household wealth and head of household's educational level, which are stable and independent of all other factors and circumstances included, one could conclude that better off households with more knowledge are in a better position to send their children to school and keep them there. Therefore, one could consider the use of direct financial support to poorer households and empowering interventions as possible solutions, especially for children living in a female-headed household.

Our study might indicate that government intervention at the institutional level might not be the sole solution. Government interventions may need to shift gradually from providing institutional support at the national or regional level, to giving support channeled through institutions, such as municipalities and schools, to households and children, or to apply solutions at both institutional and individual levels simultaneously. New government interventions, such as household socioeconomic empowerment, the national program for community empowerment or the program nasional pemberdayaan mandiri (PNPM) and cash transfer programs or bantuan tunai langsung (BLT) may be promising initiatives in this respect, next to scholarships to children from poor families.

Finally, though school availability is no barrier for children in urban areas, it is still a constraint for children in rural areas, particularly in geographically challenging areas, such as Papua Island. Our results make clear that living in village without a school or with one located a long distance away substantially increases the likelihood of children never attending school. These findings imply that building schools in rural villages and remote areas might be a solution. If this is impossible due to the low population density in remote rural areas, an alternative might be to provide a "mini-school model" for primary school, and provide boarding schools and long-distance learning systems for junior high school (ISPA 2013). This is how an important constraint to attending school could be overcome. 


\section{References}

Alisjahbana, AS . 1999. "Does demand for children's schooling quantity and quality in Indonesia differ across expenditure classes?" Journal of Population Jakarta, vol. 5, no. 1, pp. 87-114.

Anderson, D.M. 2010. In school and out of trouble? The minimum dropout age and juvenile crime. University of Washington.

Arunatilake, N. 2006. "Education participation in Sri Lanka: Why all are not in school." International Journal of Educational Research, 45 (3): 137-152.

Barrera-Osorio, F., Linden L.L., and Urquiola, M. 2008. The Effects of User-Fee Reductions on Enrollment: Evidence from a Quasi-Experiment. Columbia University Working Paper.

Becker, G.S., and Nigel, T. 1994. Human Capital and the Rise and Fall of Families, NBER Chapters." In Human Capital: A Theoretical and Empirical Analysis with Special Reference to Education (3rd Edition), pages 257-298 National Bureau of Economic Research, Inc.

Blöndal, Hawkesworth, and Choi. 2009. "Budgeting in Indonesia." OECD Journal on Budgeting Vol.9/2009.

Brooks-Gunn, J., and Duncan, G. J. 1997. "The effects of poverty on children." Future of Children, 7, 55-71.

Central Bureau Statistics (CBS) of the Republic of Indonesia. 2010. National Social Economic Survey 2010.

Central Bureau Statistics (CBS) of the Republic of Indonesia. 2011. Potential Village 2011.

Colclough, C., Rose, P., and Tembon, M. 2000. "Gender inequalities in primary schooling: the roles of poverty and adverse cultural practice". International Journal of Educational Development, 20: 5-27.

Ersado, L. 2005. "Child labor and schooling decisions in urban and rural areas: comparative evidence from Nepal, Peru, and Zimbabwe." World Development, 33(3): 455-480.

Gitter, S. R., and Barham, B. L. 2007. "Credit, natural disasters, coffee and educational attainment in rural Honduras." World Development, 35(3), 498-511.

Huisman, J., and Smits, J. 2009. "Effects of Household- and District-Level Factors on Primary School Enrollment in 30 Developing Countries." World Development, Vol. 37, No. 1: pp. 179-193.

Isolated Children's Parents' Association (ISPA) Qld Inc. 2013. Australian Education Bill 2012 - Submission 3.

Liu, F. 2004. "Basic education in China's rural areas: a legal obligation or an individual choice?" International Journal of Educational Development, 24: 5-21.

Lloyd, C.B., and Blanc, A.K. 1995. Children's schooling in sub-Saharan Africa: The role of fathers, mothers, and others. Research Division Working Paper No. 78. New York: The Population Council.

McCulloch, N., andGrover, A. 2010. Estimating the national impact of the financial crisis in Indonesia by combining rapid qualitative study with national representative surveys. Institute of Development Studies.

McNeal, R.B. 1999. "Parental involvement as social capital: Differential effectiveness on science achievement, truancy, and dropping out." Social Forces, 78,117 144.

Merton, R.K. 1968. Social Theory and Social Structure. Enlarged Edition. New York: The Free Press.

Merton, R. K. 1995. "Opportunity Structure: The Emergence, Diffusion and Differentiation of a Sociological Concept, 1930's -1950's", pp. 3-78 in F. Adlerand W.S. Laufer (eds.), The Legacy of Anomie Theory. London: 
Transaction Publishers.

Pusponegoro, N.H. 2013. Kemiskinan anak usia kurang dari lima tahun pada rumah tangga dengan rata-rata pengeluaran terletak pada kuantil pertama tahun 2008-2010 di Indonesia. SMERU. Jakarta.

Rasbash, J., Steele, F., Browne, W.J., and Goldstein, H. 2014. MLwiN manuals. Centre for Multilevel Modelling, University of Bristol.

Roberts, K. 2009. "Opportunity structures then and now." Journal of Education and Work Vol. 22, No. 5, November 2009, 355-368.

Shahnaz, L., and Naeem, S. 2012. "Why Children Never Attend School in Pakistan? Evidence from PSLM 2010-11."

Shindler, J. 2010. Characteristics of Out-of-School Children of Compulsory School Age in South Africa: What the Community Survey 2007. A 'Consortium for Research on Educational Access, Transitions and Equity (CREATE) working paper.

Sjahrir, B.S., and Kis-Katos, K. 2011. Does local governments' responsiveness increase with decentralization and democratization? Evidence from sub-national budget allocation in Indonesia. University of Freiburg, Department of International Economic Policy .

Snijders, T.A.B., and Bosker, R.J. 2012. Multilevel analysis: An introduction to basic and advanced multilevel modeling (Second edition). London: SAGE publications Ltd.

Sparrow, R. 2007. "Protecting Education for the Poor in Times of Crisis: An Evaluation of a Scholarship Programme in Indonesia." Oxford Bulletin of Economics and Statistics, 69, 99-122.

Suharti. 2013. Trends in Education Indonesia. Education in Indonesia. ISEAS. Singapore.

Suliman, E.A., and El-Kogali, S.E. 2010. "Why are the children out of school? Factors affecting children's education in Egypt."

Treiman, D.J., and Ganzeboom, H.B.G. 1990. "Cross-national comparative status attainment research." Research in Social Stratification and Mobility, 9, 105 127.

UNESCO. 2005. Children Out of School: Measuring Exclusion from Primary Education. Montreal: Institute for Statistics.

Yonezawa, A. and Muta, H. 2001. "Financing Junior Secondary Education in Decentralised Administrative Structures: The Indonesian Example." Journal of International Cooperation in Education, Vol.4 No.2 (2001) pp.109 124. http://www.djpk.depkeu.go.id retrieved 10-12-2013

http://data.unicef.org/education/secondary retrieved 08-08-2014 